\title{
An Integrated System-Oriented Model for the Interoperability of Multiple Emergency Response Agencies in Large-Scale Disasters: Implications for the Persian Gulf
}

\author{
Najmedin Meshkati ${ }^{1,2,3} \cdot$ Maryam Tabibzadeh $^{4}$
}

Published online: 27 September 2016

(c) The Author(s) 2016. This article is published with open access at Springerlink.com

\begin{abstract}
Failures in complex technological systems could have multiple dire aftermaths, including many deaths and injuries. These events, such as nuclear accidents, pose serious threats and long-lasting health and environmental consequences to workers, the local public, and possibly the whole country and neighboring regions. Such failures, given interconnectivities and interdependencies, could also have spillover effects and threaten the integrity of other systems operating in the same area. There is an essential need for effective integration and interoperability among multiple emergency response agencies, possibly from different countries, in the case of an accident in a safetysensitive industry that causes the release of hazardous materials or contaminants. This article proposes a generic integrated system-oriented model to address this urgent need. It has been applied to the Persian Gulf area and its waters as a case study because of the existence of multiple co-located, safety-sensitive industries such as nuclear power generation, offshore oil and gas drilling, seawater desalination, and seafood harvesting. The Persian Gulf region and its ecosystems are highly vulnerable, and the
\end{abstract}

Maryam Tabibzadeh

maryam.tabibzadeh@csun.edu

1 Sonny Astani Department of Civil/Environmental Engineering, Viterbi School of Engineering, University of Southern California, Los Angeles, CA 90089, USA

2 Daniel J. Epstein Department of Industrial and Systems Engineering, Viterbi School of Engineering, University of Southern California, Los Angeles, CA 90089, USA

3 School of International Relations, University of Southern California, Los Angeles, CA 90089, USA

4 Department of Manufacturing Systems Engineering and Management, California State University, Northridge (CSUN), Northridge, CA 91330, USA countries around the Gulf are tightly interdependent, with an urgent need for cooperative emergency response planning. The Black Sea and other semiclosed, water-based ecosystems can also benefit from this model.

Keywords Emergency response - Incident Command System (ICS) - Interoperability analysis · Nuclear energy $\cdot$ Persian Gulf $\cdot$ Seawater desalination

A forewarning of an evil is justified only when to the warning is joined a means of escape. (Cicero, Divination, II, 54).

\section{Introduction}

Human ingenuity has resulted in complex technological systems whose accidents rival in their effects the greatest natural disasters, sometimes with even higher death tolls and greater environmental damage. A common characteristic of these systems, such as nuclear power plants, is that sizable amounts of potentially hazardous materials are concentrated in sites under the centralized control of human operators. The effects of catastrophic breakdowns of these complex systems, created by anthropogenic or natural causes, pose serious threats and long-lasting health and environmental consequences for workers in these facilities, the local public, and possibly the whole country and neighboring regions.

The world has witnessed two major low-probability, high-consequence technological calamities with long-lasting environmental effects and regional aftermaths in just the last 5 years. The BP Deepwater Horizon offshore oil drilling platform explosion in 2010 killed 11 workers and spilled an estimated 171 million gallons of crude oil into the Gulf of Mexico (NRDC 2015) - the total cost of the 
damage could amount to USD 68.2 billion (Eaton 2015). The 2011 Fukushima Daiichi nuclear power plant accident in Japan released radiation to the atmosphere and spilled thousands of gallons of contaminated radioactive water into the Pacific Ocean affecting sea life (Buesseler 2014). To this day contaminated water is seeping into the ocean. The emergency responses to these two disasters have been mired in all sorts of system-related problems and issues. The lack of interoperability among different responding agencies and organizations seriously affected consequence mitigation and disaster recovery. Thinking about the unthinkable and developing a badly needed cohesive emergency response framework should be of paramount importance for public policy and cognizant governmental officials who will be faced with planning and executing emergency responses.

In some parts of the world, such as the Persian Gulf, coastal countries should be able to imagine and be prepared to respond to a massive oil spill or radionuclide release into the water. Future events could have much more catastrophic effects on these countries' ecosystems and people's lives than the Gulf of Mexico and Fukushima disasters combined.

The Persian Gulf is facing a future with serious implications for emergency response planning. The increasing reliance on seawater desalination for producing potable water in the Persian Gulf Cooperation Council (GCC) member states (ranging from $70 \%$ in Saudi Arabia to $99 \%$ in Qatar); the expected operation of at least five newly-built nuclear power reactors in the next 5 years (Iran's single operational reactor at the Bushehr plant, and the United Arab Emirates-Abu Dhabi's four under-construction reactors at the Barakah plant); ongoing offshore oil and gas drilling; and the routine heavy maritime traffic of different naval and commercial vessels have significant combined effects on sea life and the ecosystem.

A major oil spill or radiation contamination could have spillover effects and seriously hamper the operation and cause closure of seawater desalination plants, which are the lifeblood of most of the countries around the Persian Gulf. The effects of the interconnectivities and interdependencies of several technologies and industries in the same region, especially in the Middle East, "are of growing concern and play an important role in many risks now appearing on the horizon," according to a recent report by Allianz (Allianz Global Corporate \& Specialty 2015, p. 30), the world's largest insurance company. The report suggests that "more awareness of risks linked to increasing interconnectivity and interdependency" should be raised (Allianz Global Corporate \& Specialty 2015 , p. 30 ). Thus, there is an urgent need in/for the Persian Gulf countries to address the important issue of interdependencies and develop regionally coordinated emergency response planning.
The major objective of this article, with the help of lessons from the past, is to provide a system-oriented model for understanding and designing the interoperability of multiple emergency response organizations and their command, control, and communication operations in largescale disasters. This is done by providing (1) a brief description of the state of affairs in the Persian Gulf, a semiclosed area that is home to multiple safety-sensitive industries that face the risk of major accidents and toxic releases; (2) a brief overview of a challenging issue that is hampering emergency responses to recent major disasters; (3) an analysis of the major subsystems of an emergency response system, illustrating the critical interactions of those subsystems in a three agency emergency deployment; (4) a model to specify the needed collaboration and interoperability of key entities and players in a sample of two major safety-sensitive industries (such as nuclear power generation, offshore oil and gas drilling, and seawater desalination) in a typical Persian Gulf country at the time of an emergency, and expanding the proposed model with a bilateral and multilateral framework for the collaboration and cooperation of multiple agencies from different countries; (5) some specific recommendations for the implementation of an integrated, system-oriented model for emergency response; and (6) thoughts on the generalizability of the proposed model and its application to similar areas and settings such as the Black Sea.

The model proposed in this study is generic in nature. It applies to the emergency response of different agencies, possibly from different countries, to an accident of a safety-sensitive industry that causes the release of hazardous materials or contaminants that could affect other vital industries in the surrounding area. It has been applied to the Persian Gulf setting as a case study because of the existence of multiple safety-sensitive industries (Meshkati et al. 2016).

\section{Seawater Desalination and Nuclear Power in the Persian Gulf}

The Persian Gulf is a marine environment surrounded by eight countries (Iran, Iraq, Saudi Arabia, Oman, United Arab Emirates (UAE), Qatar, Bahrain, and Kuwait). According to the Regional Organization for the Protection of the Marine Environment's State of the Marine Environment report (ROPME 2013), the total population of these countries was around 150 million in 2010 and is expected to reach 200 million by 2030 . Given the land shortage in Kuwait, Qatar, and the UAE, the majority of the population lives in urban settlements on the coast (Fig. 1) and is heavily dependent on marine ecosystems (ROPME 2013). 


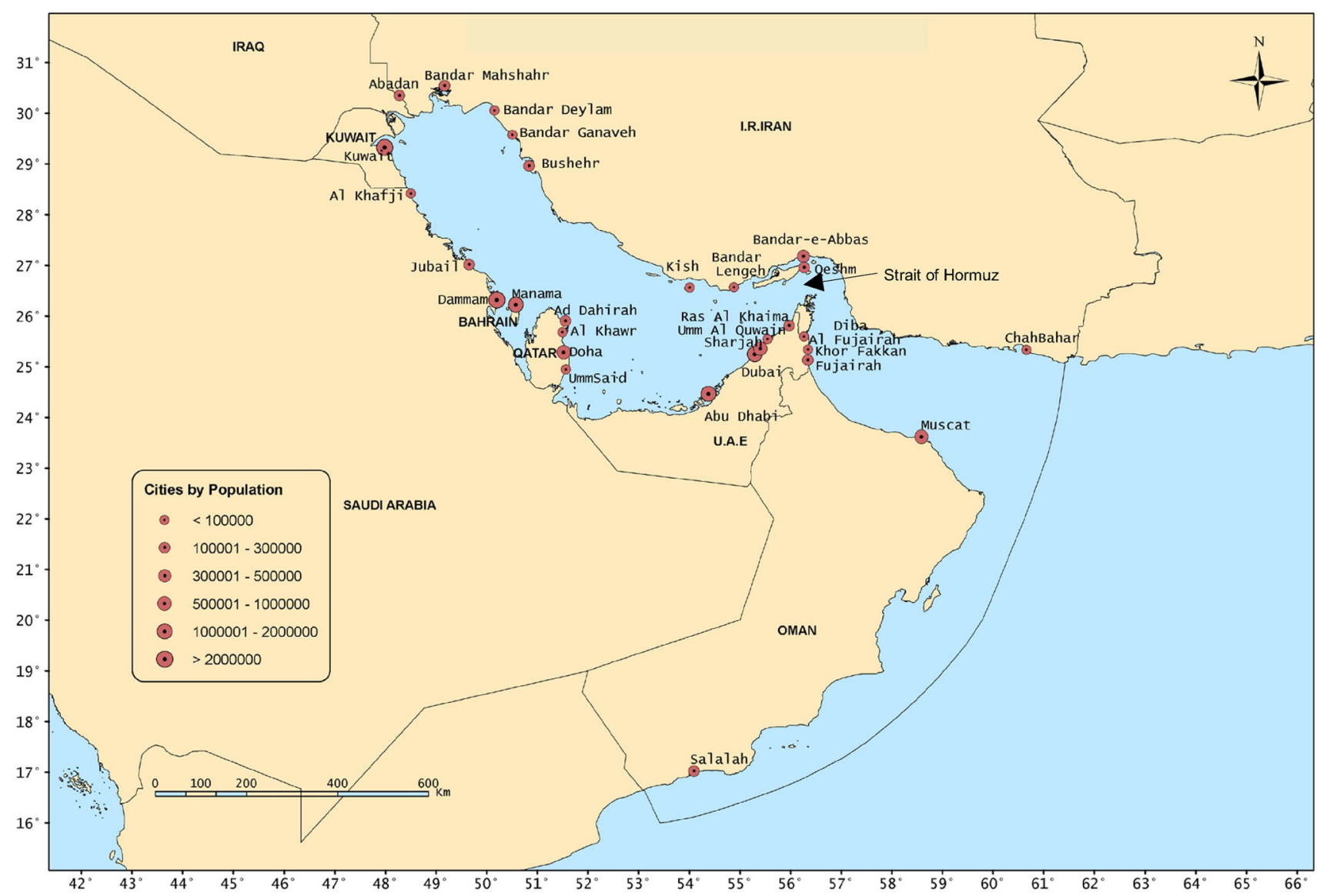

Fig. 1 Major cities in the Persian Gulf. Source ROPME (2013, p. 6). Reprinted with permission of ROPME

There are approximately 800 offshore oil and gas platforms and 25 major oil terminals situated in the Persian Gulf region (Haapkylai et al. 2007). Some 25,000 tankers pass through the Strait of Hormuz annually and transport approximately $60 \%$ of all the oil shipped globally (Happkylai et al. 2007). Oil exploration, production, transport, and discharges of mainly drilling wastes, operational sludge, and oily fluids from unused fracturing fluids or acids are major contributors to pollution levels in the Persian Gulf (Madany et al. 1998; ROPME 2013).

The offshore oil and gas industry of the Persian Gulf has experienced serious accidents and spills. On 2 October 1980 an exploratory well blew out for 8 days and cost the lives of 19 men. Saudi Arabia, Qatar, Bahrain, and the United Arab Emirates were threatened by the spill. In 1983, the Nowruz Oil Field in the Iranian territorial waters was involved in a number of oil pollution incidents. Catastrophic large-scale events also took place in the Persian Gulf during and after the 1991 Gulf War. Between 0.5 and 1 million tons of oil were released into the coastal waters. On 21 April 2011 a fire broke out on the Maersk Oil Qatar offshore platform. All of these events demonstrate the need to research and determine precursors of potentially disastrous incidents at major offshore oil platforms such as Qatar's PS-2 and PS-3, operating within the Maydan Mahzam and Bul Hanine fields, respectively, and also many platforms that are expected to operate in the North Gas Field of Qatar and Iran's South Pars Field in the future.

The Persian Gulf is a semiclosed shallow body of water with an average water depth of $36 \mathrm{~m}$, a maximum internal depth of $94 \mathrm{~m}$, and very high salinity (Sale et al. 2011). The dominant path of flow is counterclockwise (Fig. 2). Ocean water with normal salinity enters the Persian Gulf from the Strait of Hormuz, flows westward along Iran's coast and turns southeast to exit the Persian Gulf, saltier than it started, after passing by the coastlines of the southern Persian Gulf countries (Reynolds 1993). Water circulation in the Persian Gulf is estimated to take between 2 and 5 years (Reynolds 1993). In another word, a water molecule that enters the Persian Gulf through its only opening to the "open" sea from the Strait of Hormuz needs more than 2 years to circle and eventually leave the Gulf.

The Persian Gulf is one of the highest-salinity waters in the world (Swift and Bower 2003). The salinity level is more than 40 parts per thousand in most of the Gulf and in some limited areas can exceed 50 parts per thousand 
Fig. 2 Surface currents and circulation processes in the Persian Gulf. Source Reynolds (1993). Figure copied from the online version of the article by Reynolds (August 1993, p. 49) at http://www.rmrco.com/docs/ pub93_PersianGulf_MarPolBul. pdf

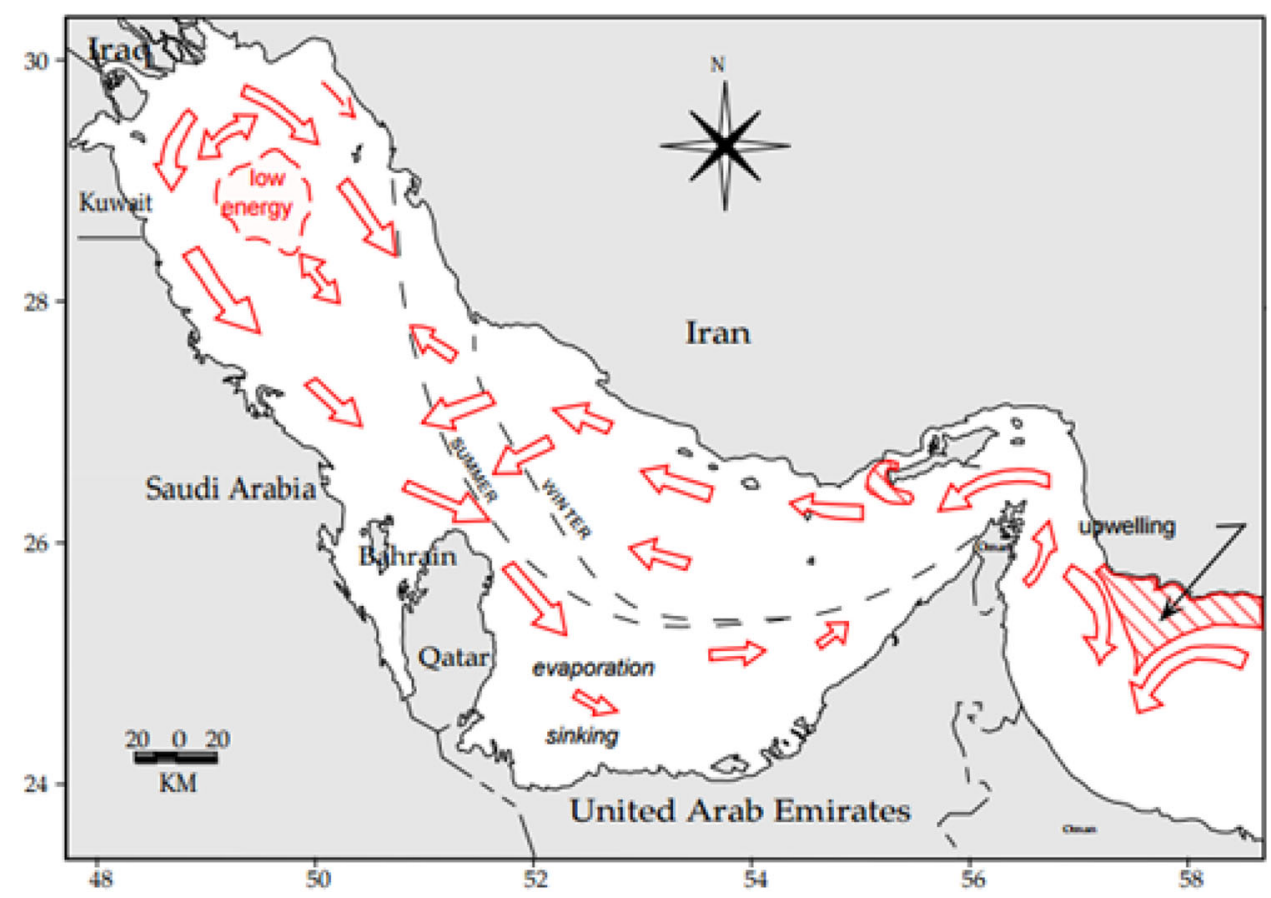

(Wang et al. 2013). According to the World Wildlife Fund for Nature in Dubai, the Persian Gulf's salinity level used to be 32 parts per thousand 35 years ago (Alderman 2010). Water salinity is steadily increasing for many reasons, chief among them the wastes (brine and heated sludge, which includes other unwanted byproducts of the desalination process) from the many seawater desalination plants that dump these wastes back into the sea. This poses a serious threat to the ecosystem and marine life in the Persian Gulf (Alderman 2010). As water becomes saltier, more energy is required to desalinate the water. This causes other environmental issues, because much of the region depends on petroleum to fuel the desalination plants.

\subsection{Seawater Desalination in the Persian Gulf}

The Persian Gulf has the largest number of desalination plants in the world (Fig. 3), with a total capacity of 11 million $\mathrm{m}^{3}$ per day in 2008; this was equivalent to $45 \%$ of global daily water production (Lattemann and Höpner 2008). In the past 30 years, the capacity of the desalination plants has increased from 5 million $\mathrm{m}^{3}$ per day in 1985 to 24 million $\mathrm{m}^{3}$ per day in 2012 (Saif 2012). It has been projected that "by 2050-desalination irrespective of its fuel source, would account for $76 \%$ of all water needs for the region for all sectors" (Trieb and Mullersteinhagen 2008; cited in Saif 2012, p. 8). The Arab countries in the Persian Gulf region are widely dependent on this water body for their drinking water needs. Almost all of these countries will have no other options than the Persian Gulf for water.

Based on a report by the Gulf Research Center (Bachellerie 2012) and other sources, the contribution of seawater desalination to producing potable water for the Arab countries of the Persian Gulf is significant:

- United Arab Emirates $>90 \%$ (Dubai City $98.8 \%$, Sharjah City $80 \%$ )

- Qatar $99 \%$

- Kuwait $95 \%$

- Oman $80 \%$

- Bahrain $>80 \%$

- Saudi Arabia $>70 \%$

Iran is facing severe drought conditions. Former Iranian Minister of Agriculture, Isa Kalantari, warned about the possibility that "approximately 50 million people, $70 \%$ of Iranians, will have no choice but to leave the country in the coming years because of water scarcity" (Kalantari 2015). Iran's share of water demand met by desalination grew from around $0.2 \%$ in 2004 (FAO 2009) to around $1 \%$ in 2010 (World Bank 2012). Although this amount is small compared to the amounts in the Arab countries, officials in Tehran are strategically considering the Persian Gulf as the primary water source for not only the southern parts of the country but also for the central parts in the future. Projections suggest that in 10 years, approximately 9 million people, who will account for almost $10 \%$ of the country's population, will depend on desalinated water in the southern areas of Iran (Mivehchi 2015). 


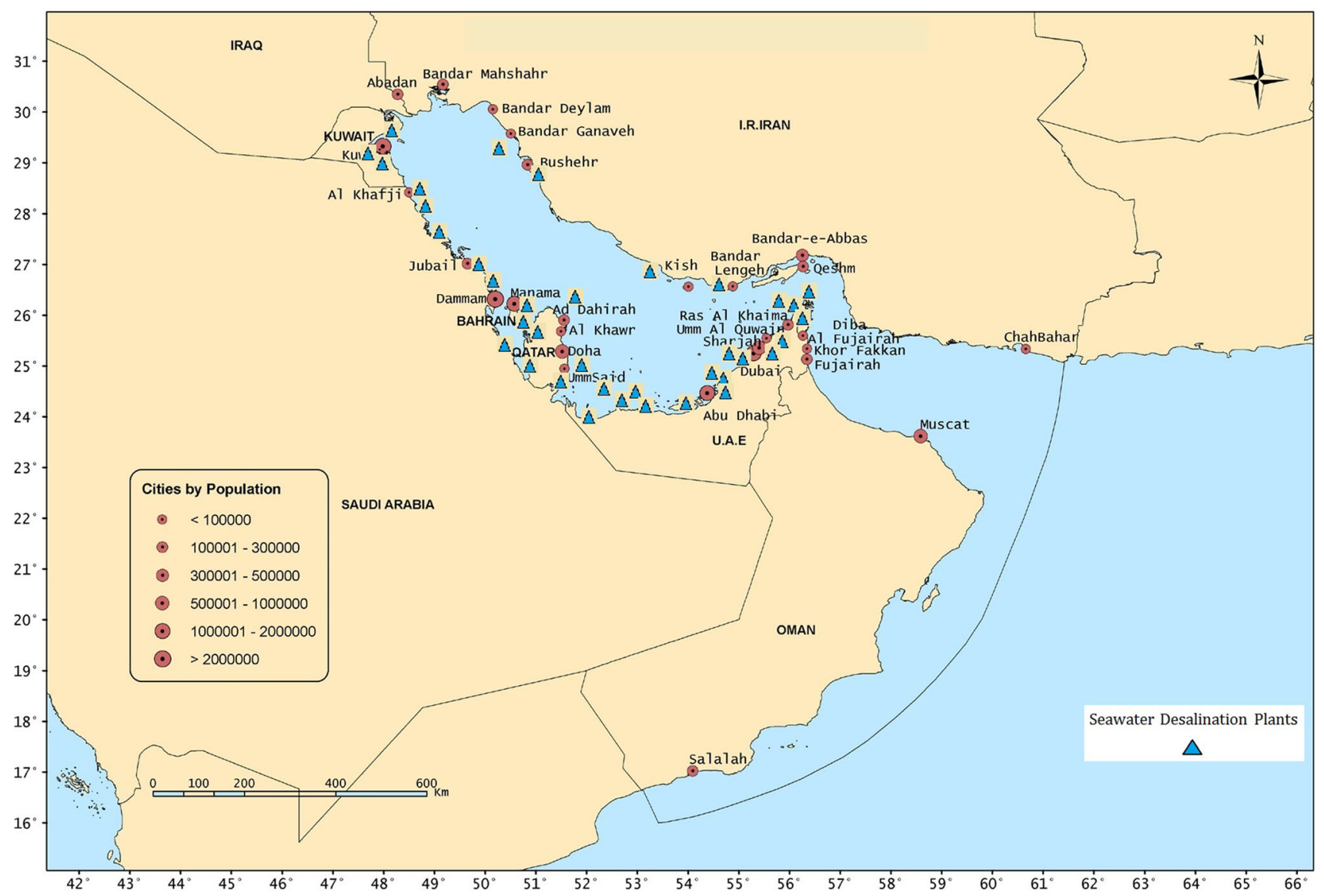

Fig. 3 Location of major seawater desalination plants in the Persian Gulf. Source ROPME (2013, p. 6); seawater desalination plant data from World Bank (2012)

\subsection{Nuclear Power in the Persian Gulf}

It seems that the Persian Gulf region is destined to be dotted with nuclear power plants in the next few decades (Fig. 4) and will be the world's main market for nuclear reactor vendors in the near future. Both the UAE and Saudi Arabia have plans to have operational nuclear power plants before 2020. The UAE has signed contracts with a South Korean consortium to build four reactors-Barakah Units 1 through 4-in Abu Dhabi. As of August 2016, the "overall construction of the four units is now $60 \%$ complete $[\ldots]$ Unit 1 is scheduled to start up in 2017 , with the other units following at yearly intervals [...] all four units at the [Barakah] site should be in operation by 2020" (World Nuclear News 2016a).

Saudi Arabia announced plans to construct 16 nuclear power reactors over the next 20 years, with the first reactor on line in 2022 (World Nuclear Association 2015a). The siting decision for these reactors has not been made yet. It is expected that a sizable number of the reactors be located on the Persian Gulf coast. Other Persian Gulf states such as Bahrain, Kuwait, and Qatar have also expressed interest in nuclear power for electricity generation and seawater desalination purposes (World Nuclear Association 2015b).

Iran has one operational nuclear power plant on the Persian Gulf coast in Bushehr and plans to build more: "the construction of the second one will start soon... and there will be nuclear plants in most parts of the Bushehr province," stated President Rouhani when he visited the city of Bushehr in early December 2013. Russian Foreign Minister, Sergei Lavrov, confirmed during his visit in Tehran in the same month that Iran "plans to build more power units identical to the Bushehr one" (Russia Beyond the Headlines 2013). The president of the Atomic Energy Organization of Iran has recently announced that the foundation for two new nuclear reactors at Bushehr on 10 September 2016 has been laid down, "and the country has a long-term target of $20 \mathrm{GWe}$ (Gigawatt electric) of nuclear capacity $[\ldots]$ the country is also looking to utilize small modular reactors (SMRs) of up to $100 \mathrm{MWe}$ for electricity and desalination in remote areas of the country" (World Nuclear News 2016b).

The Persian Gulf countries should learn from the Chernobyl and Fukushima nuclear accidents and look 


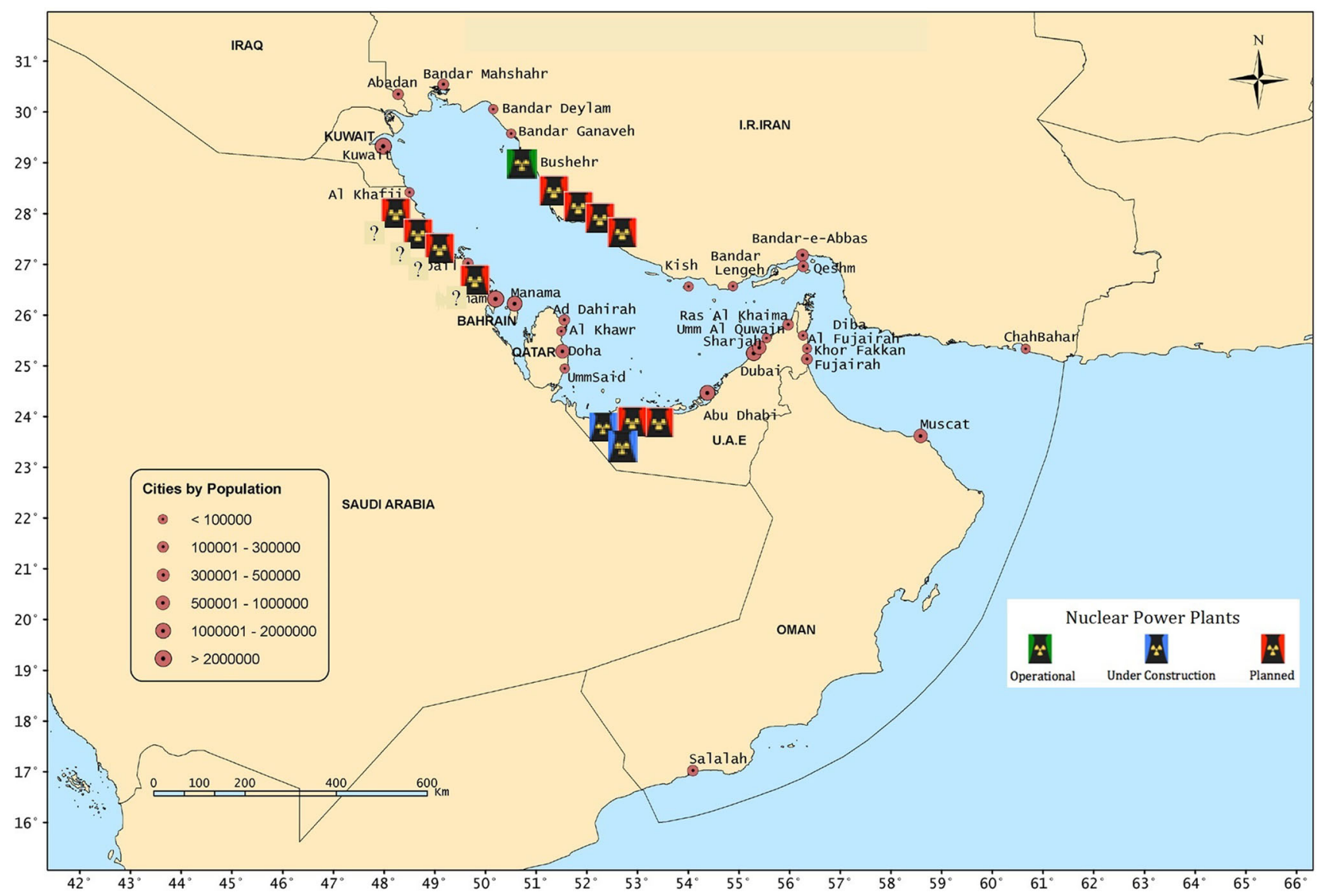

Fig. 4 Location of nuclear power plants in the Persian Gulf (question marks indicate the unknown exact location and number of planned nuclear power plants by the Kingdom of Suadi Arabia on the Persian
Gulf coast). Source ROPME (2013, p. 6); nuclear power plant data from World Nuclear News (2015a, 2016a, b)

ecosystem interactive sphere. It delineates major negative consequences and their undesirable interactive effects.

\section{The Incident Command System (ICS) Concept and Emergency Response}

The concept of an incident command system (ICS) has been around for several decades. Its origin goes back to the response to wildfires in California in the late 1960s (Jensen and Waugh Jr 2014). The ICS, according to the Department of Homeland Security (2004, p. 14), is a "management system designed to enable effective and efficient domestic incident management by integrating a combination of facilities, equipment, personnel, procedures, and communications operating within a common organizational structure."

The ICS is designed to integrate resources not only within, but also across organizations (Bigley and Roberts 2001). The ICS should be able to constantly reconfigure change and modify strategic direction, switch tactics as an incident unfolds, and respond accordingly. "ICS-based 


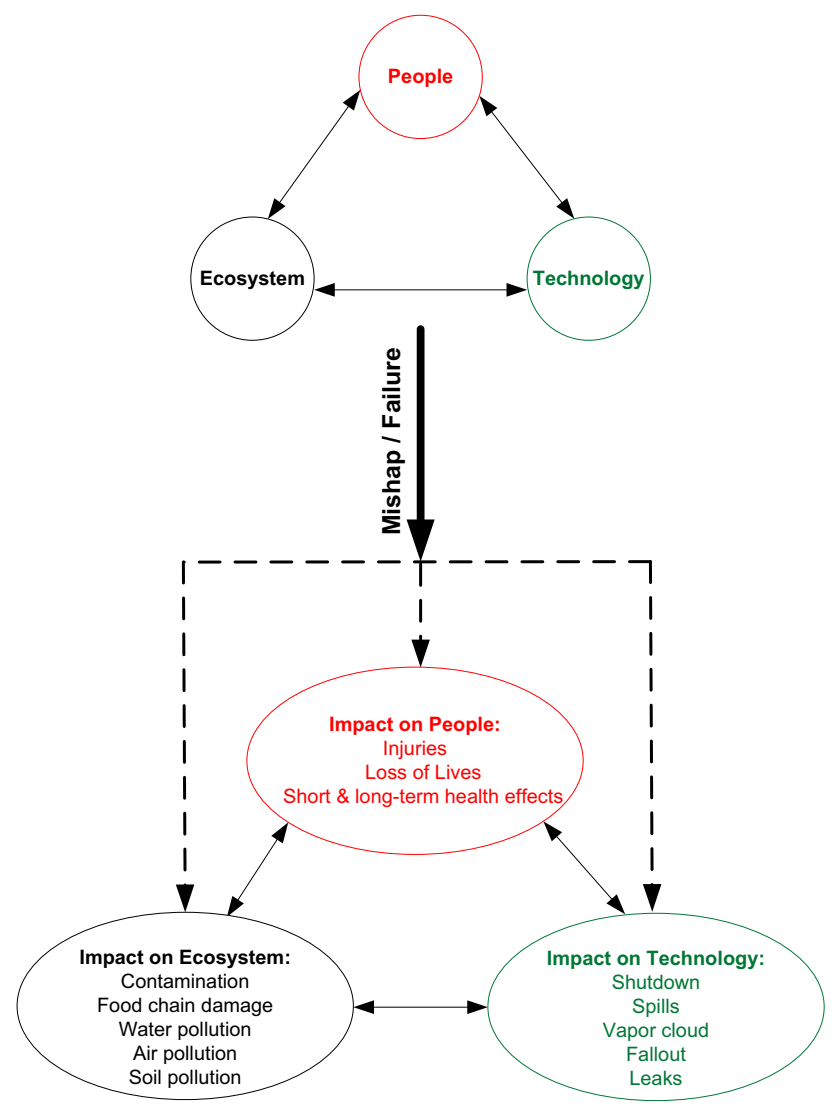

Fig. 5 Adverse consequences of a complex, large-scale technological system failure and their interactive effects

organizations can coordinate diverse resources to achieve specific objectives under turbulent, severely time-constrained and hazardous conditions" (Bigley and Roberts 2001, p. 1284).

Many overlapping studies have identified factors for the effective implementation and successful operation of an ICS. Based on an extensive review of ICS literature, Jensen and Waugh Jr (2014) identified such factors as: characteristics of the individual participants; nature and structure of individual operating organizations; leaders within the system and their pre-incident relationships with one another; the pre-incident and post-incident characteristics of the response network; the local area and surrounding culture; the hazard event, its nature, and scale; and the use of ICS in the initial stages of response and on an ongoing basis.

Bigley and Roberts (2001) identified three interrelated conceptual categories that lead to organizational reliability and effective ICS performance when responding to hazardous and dynamic emergency situations:

(1) structuring mechanisms, which include evolving and elaborating structures with reconfiguration capability, role switching, and reassignment of personnel to different positions within organizations, authority migrating when for instance a supervisor tends to defer to lower-level experts, and system resetting that refers to the capability to retract, reconfigure, and reapproach the incident;

(2) organizational supports for constrained improvisation, a disciplined approach to fully utilize expertise and resourcefulness of individual members to improvise with respect to tools, rules, and routines and sometime deviation from standard operating procedures in the interest of the final outcome; and

(3) cognition management methods, which include and ensure collective operational representation and shared mental models of individual members of the ICS team.

There is no doubt that ICS is an effective and proven model to respond to an emergency. However, according to many studies, the ICS design, implementation, and application should be highly flexible and sensitive to the idiosyncrasies of the targeted emergency. This applies particularly when myriad organizations of multiple types, composed of individuals from different backgrounds, training, and expertise, are responding to different hazards, operating in different geographical areas, and with different values (Jensen and Waugh Jr 2014).

\section{Serious System-Related Problems of Emergency Reponses to Recent Disasters}

There have been many concerns about ICS, its poor flexibility and scalability, and "lack of use, misuse, underuse, [and] partial use" as a root cause of inadequate and insufficient response to recent emergencies (Jensen and Waugh Jr 2014, p. 12). According to Clarke (1999) who has critically studied various emergency response plans, some of these plans envisioned a functional ICS, but have minimal actual instrumental utility and warrant the label "fantasy document" (p. 2).

Lingering system-related issues have been identified as major problems that influenced the effectiveness of emergency responses to the last several major natural and anthropogenic disasters. During the emergency response to the 9-11 terrorist attack in New York City, there were many interoperability problems between the two main responding agencies, the Fire Department of New York (FDNY) and the New York Police Department (NYPD). According to an extensive analysis by McKinsey \& Company (2002), outdated radio equipment and monitoring systems were major contributing factors to the problems with the response and seriously hampered the needed communication between emergency and first responders from the two agencies in the field. 
Tierney (2006), after observing the chaotic state of the emergency response to Hurricane Katrina in 2005, asserted "4 years after September 11 and a few weeks after Hurricane Katrina, the protection of our nation against extreme events is being managed by a bloated, myopic, and incompetent bureaucracy that has undermined the nation's ability to be resilient in the face of disasters-and terrorism-and drastically underinvested in measures that would truly make the nation safer."

Emergency response to the BP Deepwater Horizon accident and oil spill in 2010 in the Gulf of Mexico has been fraught with many inadequacies, unpreparedness, and fragmented and piecemeal approaches of multiple emergency responders. In addition to the lack of coordination and communication and the role ambiguity among multiple emergency responders - the company's own as well as local, state, and federal agencies-serious system- and interoperability-related issues were prevalent and significantly hampered consequence mitigation and recovery (Birkland and DeYoung 2011).

An exhaustive review of the emergency response to the BP Deepwater Horizon accident by the US Coast Guard (USCG 2011) identified many inadequacies and lack of preparedness of local Area Contingency Plans (ACPs). These were boldly noted in the USCG critical review, as well as problems with "the interoperability of each Sector's ACP with the Regional Response Plan" (USCG 2011, p. 18). One of the noteworthy recommendations of this report deals with the fragmented nature of emergency planning and response and the lack of overall coordination in the Gulf of Mexico: "In the Gulf of Mexico or anywhere offshore oil production occurs, there must be direct linkage between the Oil Spill Response Plan (OSRP) and local ACPs" (USCG 2011, p. 6). This recommendation has important implications in the context of the Persian Gulf, a region that suffers from a fragmented system of eight nationally driven emergency response structures and has no overarching, integrated emergency response framework to coordinate the efforts of eight countries to deal with natural and man-made disasters and their secondary effects.

In response to the many observed problems and shortcomings of the emergency response to the Deepwater Horizon accident, the National Commission on the BP Deepwater Horizon Oil Spill and Offshore Drilling (2011) made a series of specific recommendations with respect to better planning, organization, and communication among emergency responders.

Many of these issues were also identified during the emergency response to the 2011 Fukushima Daiichi nuclear accident in Japan (Lochbaum et al. 2014). According to the National Academy of Sciences and National Research Council's extensive study of this accident (NAS/NRC 2014), there were a series of vulnerabilities and inadequacies in the emergency response plan in Japan: "Decision-making processes by government and industry officials were challenged by lack of reliable, real-time information on the status of the plant, offsite releases, accident progression, and projected doses to nearby populations"; and "Coordination among the central and local governments was hampered by limited and poor communication" (NAS/NRC 2014, p. 216).

\section{The Need for a System-Oriented Model to Address Vital Interoperability Factors for the Emergency Response to a Technological Disaster}

An emergency response operation can be considered as a socio-technical system that involves interacting people, material, equipment, and procedures. As such, it can be characterized as a dynamic system with many internal interactions and feedback loops. A simplified model to analyze a technological system is presented below.

\subsection{Major Subsystems of a Technological System: Human-Organization-Technology (HOT)}

Stability, safety, and the efficient operation of technological systems, as well as their ability to tolerate environmental disturbances, is a function of the interactions among their human (that is, personnel and organizational) and engineered subsystems. The survival of technological systems is dependent on the nature, formation, and interaction of their Human, Organizational, and engineered (Technological) [HOT] subsystems (Meshkati 1992, 1995). The connection of these three (HOT) subsystems, in the context of the total system, is represented in Fig. 6. This simplified and symbolic diagram shows one critical system's reality - the role of each subsystem as a link in a chain -in the integrity of the whole system. It does not show all the needed subsystems' interactions and interrelationships.

The chain metaphor is helpful in understanding the effects of the output, or produced service by the system, on its individual subsystems. Any increase in the output level or the capacity utilization rate imposes strains on all subsystems. The chain (system) could break down if any link breaks down. This may occur if either all the links (subsystems) are not equally strong and designed for handling the additional load, or if they are not adequately prepared and reinforced to carry the extra load in a sustainable fashion. According to many studies, a majority of complex, large-scale technological systems' accidents have been caused by breakdowns of the weakest links in this chain, most often the human or organizational subsystems (for further information see IAEA 1988; Meshkati 


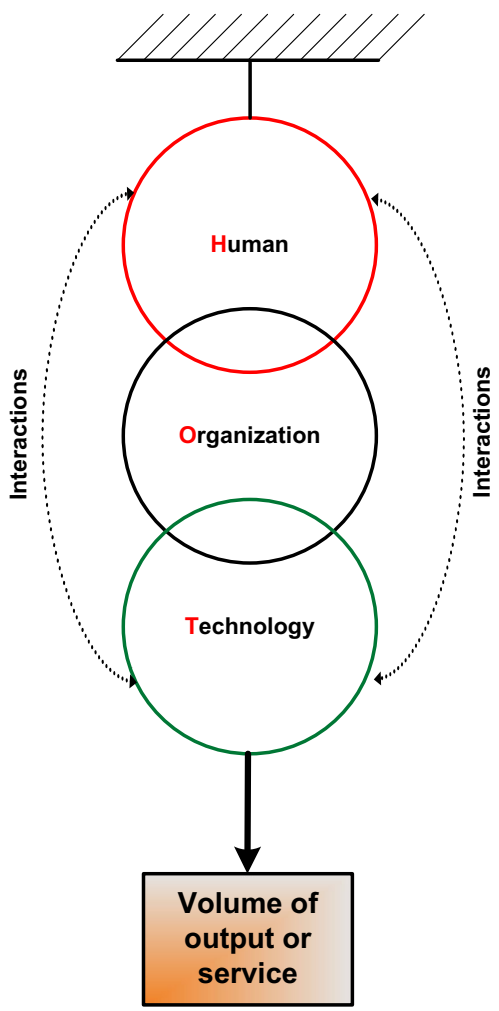

Fig. 6 Major subsystems of a large-scale, complex technological system. Source Adapted from Meshkati (1995)

1990, 1991, 1992; NAE/NRC 2011; NAS/NRC 2014; Tabibzadeh 2014; Tabibzadeh and Meshkati 2014a, b, 2015; Meshkati and Khashe 2015).

The HOT metaphor of this study is one of many abstractions that can be used to demonstrate the interactions of the human, organization, and technology subsystems of a technological system. There have been other characterizations such as the Man-Technology-Organization (MTO) perspective, which was introduced at the Swedish Nuclear Power Inspectorate (Swedish Radiation Safety Authority) (Rollenhagen 1997; Skjerve and Kaarstad 2014). The MTO perspective, like HOT, attempts to understand and promote safety in industrial processes by considering the role of their components/subsystems as well as their interactions. There could be other equally helpful characterizations of the three components/subsystems, such as a Venn diagram or a triangle, to further demonstrate the importance of this three-way interaction. One advantage of the HOT metaphor is its chain depiction of the relationship and interconnections of the three subsystems and the notion that the integrity of the whole system depends on the integrity of each link in the chain.

\subsection{The HOT Framework Application to Analyze and Design of Interoperability Requirements for Multiple Emergency Response Agencies}

The three HOT subsystems could be considered as main system components and constitute the foundation of interaction between different key players and first responders involved in emergency response. Figure 7 shows three interoperating emergency responders that interact with each other across the three human, organization, and technology components. These three components and layers of interaction are not separated from each other. They can influence each other significantly, and this impact is reflected in the chain representation. This model can be generalized to illustrate the interaction of a larger number of organizations with each other.

In the human component, elements such as culture, language, shared mental model between individuals, as well as some issues related to Crew Resource Management (CRM) are analyzed. An issue with any of the stated elements can be the contributing cause of miscommunication or ineffective interaction between key players. The analysis of interoperations in the organization layer includes different elements. Analyzing the structure, functional or matrix, for example, of each involved organization and how compatible it is with the organizational structure of other players is one type of analysis in this layer. Evaluating the compatibility of existing Standard Operating Procedures (SOPs) as well as Emergency Operating Procedures (EOPs) within each involved organization is another important component in analyzing the effectiveness of interoperations among key players. The development of procedures to guarantee seamless connectivity and information assurance every time key players interact with each other throughout all regular or disaster-response operations of a nuclear incident, for example, is critical (Garwin et al. 2004).

Finally, the interacting key players need to ensure effective interoperation at the technology level. The compatibility of equipment and devices used in disaster-response operations is one main manifestation of such effective interoperation. The interactions in the framework would also enable the smooth interoperability of a unified incident command center, composed of emergency responders working with the key players. This issue was 


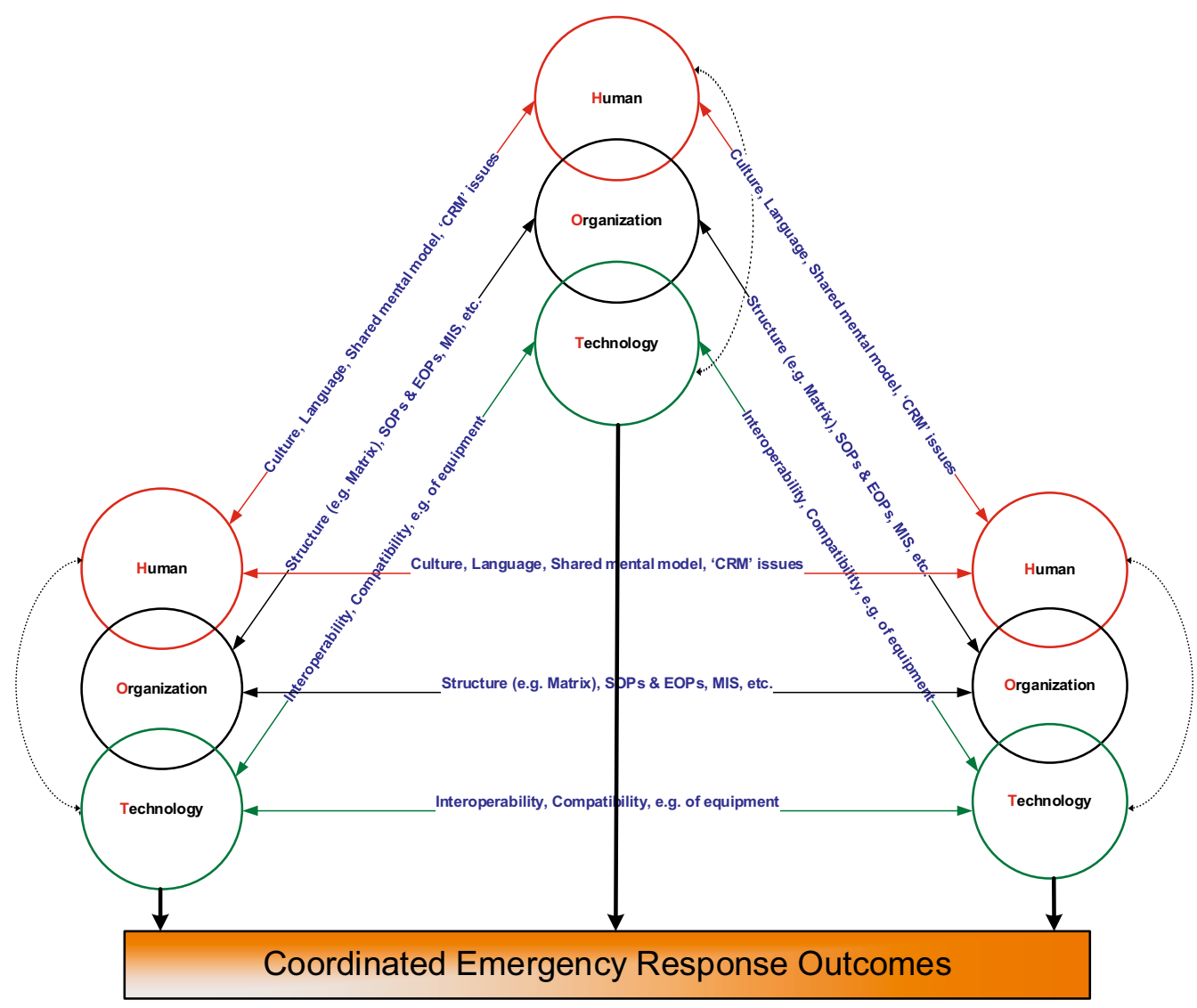

Fig. 7 Interoperations of three first responders across the human, organization, and technology (HOT) subsystems during an emergency response, and factors that affect their effectiveness. Source Adapted

pointed out by McKinsey \& Company (2002) for the 9-11 disaster as well.

\section{Proposed Model for Coordinating Intra- and Inter-Country Emergency Response Agency Activities}

In a typical large-scale natural or man-made disaster, several emergency response agencies from the host country, possibly from neighboring regions, and in the case of earthquakes and tsunamis from around the world converge to help. Each of these agencies can be considered as a HOT system. As such, the protocols and procedures for interactions and the interoperability of their composing subsystems with each other should be foreseen and proactively addressed.

\subsection{A Model for Needed Intra-Country Coordination and Collaboration Among Responsible Actors and Entities}

The proposed model attempts to systematically delineate the coordination and collaborations of related organizations from Meshkati (2010). SOPs standard operating procedures, EOPs emergency operating procedures, MIS management information system

that are needed within each country, as applied to the Persian Gulf context. The foundation of this model is a framework developed by Rasmussen (1997) that captures socio-technical interactions within organizational hierarchies (Fig. 8) and illustrates factors that affect the operations and safety of a complex technological system delineated in interactive layers. Management, staff, and work occupy the three lower levels. This system-operating company also interacts with higher-level regulators and associations. Government occupies the topmost level of the interactive hierarchy.

The proposed model (Fig. 9) shows the necessary interactions between key entities that affect the safety and emergency response of a sample of two, among several, major safety-sensitive industries-for example, nuclear power, offshore oil and gas drilling and seawater desalination-within one country (intra-country interactions) operating in the Persian Gulf.

Each of the two industries and their socio-technical interactions with regulatory bodies and government is based on the model by Rasmussen (1997). The four bottom levels of each hierarchy represent the company, which is the studied industry in the context of this article, 
Fig. 8 Nested levels of decision making involved in operations and risk management of a complex technological system. Source Rasmussen and Svedung (2000, p. 11), originally appeared in Rasmussen (1997). Reprinted with permission from the Swedish Rescue Services Agency

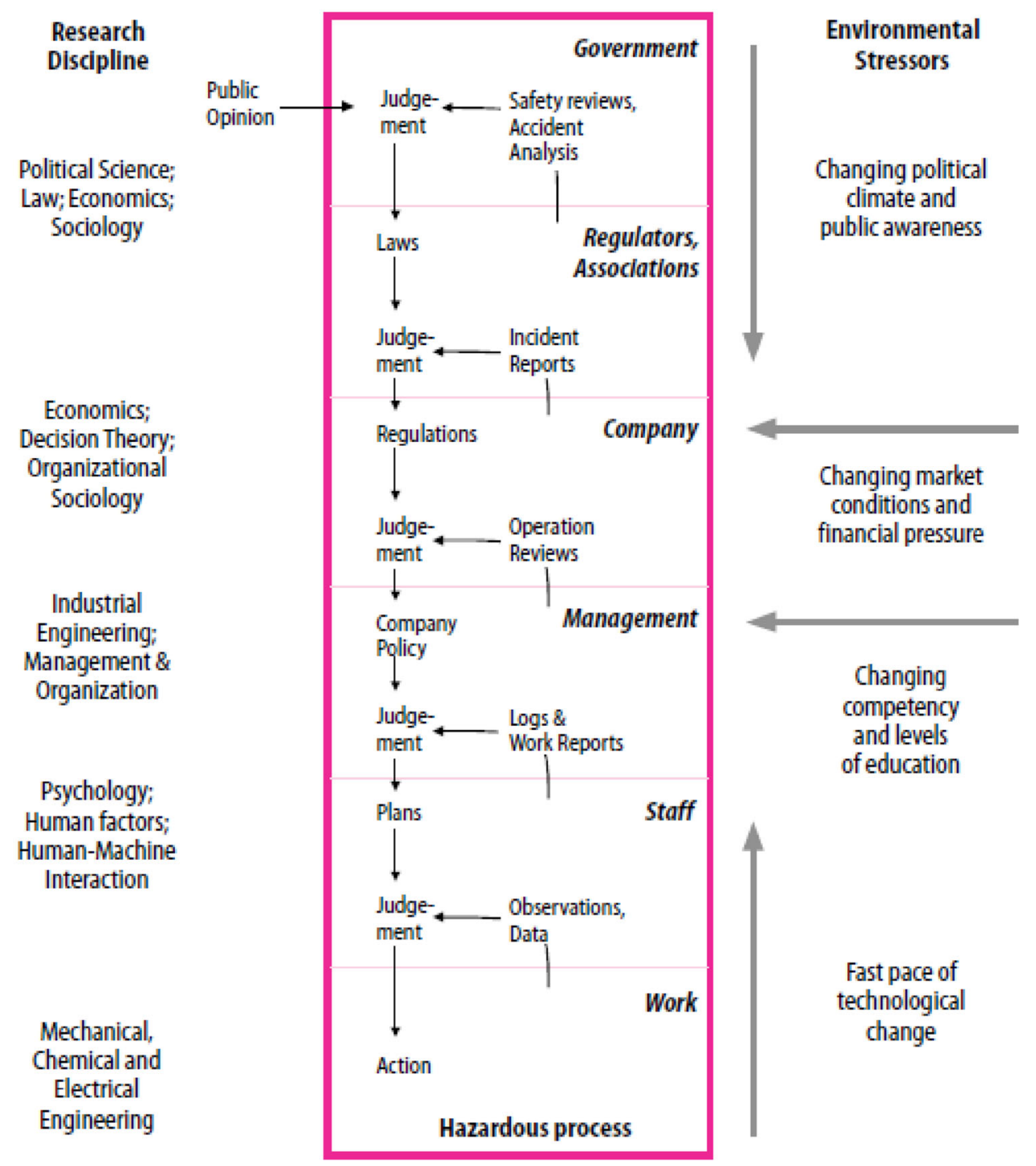

management, staff, and work. Each industry needs to interact with related regulatory bodies as well as the government of that country. This interaction has been captured in the two upper layers of each hierarchy.

Referring to Fig. 9, seawater desalination and nuclear power industries, for example, have to interact with each other on every level of the illustrated hierarchy for each of these industries. Consider Iran as one of the stakeholder countries in the Persian Gulf. Within the four bottom levels of each hierarchy, the close and effective collaboration and interoperation of the seawater desalination and nuclear power industries is needed on the company and management levels, and it is recommended on the staff and work levels. The regulatory bodies of each of these two industries also need to interact with each other in order to make sure that the enforced rules and regulations within these industries are aligned. Finally, there is the government level in each of these two hierarchies, which will be the same. A similar intra-country level of collaboration and interoperation needs to be considered and analyzed for the other Persian Gulf countries.

In an ideal world, tight collaboration and interactions among all layers, including the lower levels, is preferable. However, close interoperation between the two equivalent hierarchical levels of the seawater desalination and nuclear power industries could decrease towards the bottom of the hierarchies due to real-world realities. The importance of the need to collaborate and interact is illustrated by the thickness and color of the circles around the equivalent hierarchical levels (Fig. 9).

The interdependency of safety-sensitive industries is significant. The vulnerability and risk exposure of the Persian Gulf seawater desalination plants to oil spills and other contaminations, for example, could easily force their closure. The 1994 Seki oil tanker incident in the UAE would have turned into a major disaster if the spilled oil 
Fig. 9 Proposed model of the necessary interactions between key entities that affect the safety and emergency response of a sample of two major safetysensitive industries (nuclear power, offshore oil and gas drilling, and seawater desalination) in a Persian Gulf country, for example, in Iran or the United Arab Emirates. Source Adapted from Rasmussen and Svedung (2000)

\section{Country X; e.g. Iran or UAE}

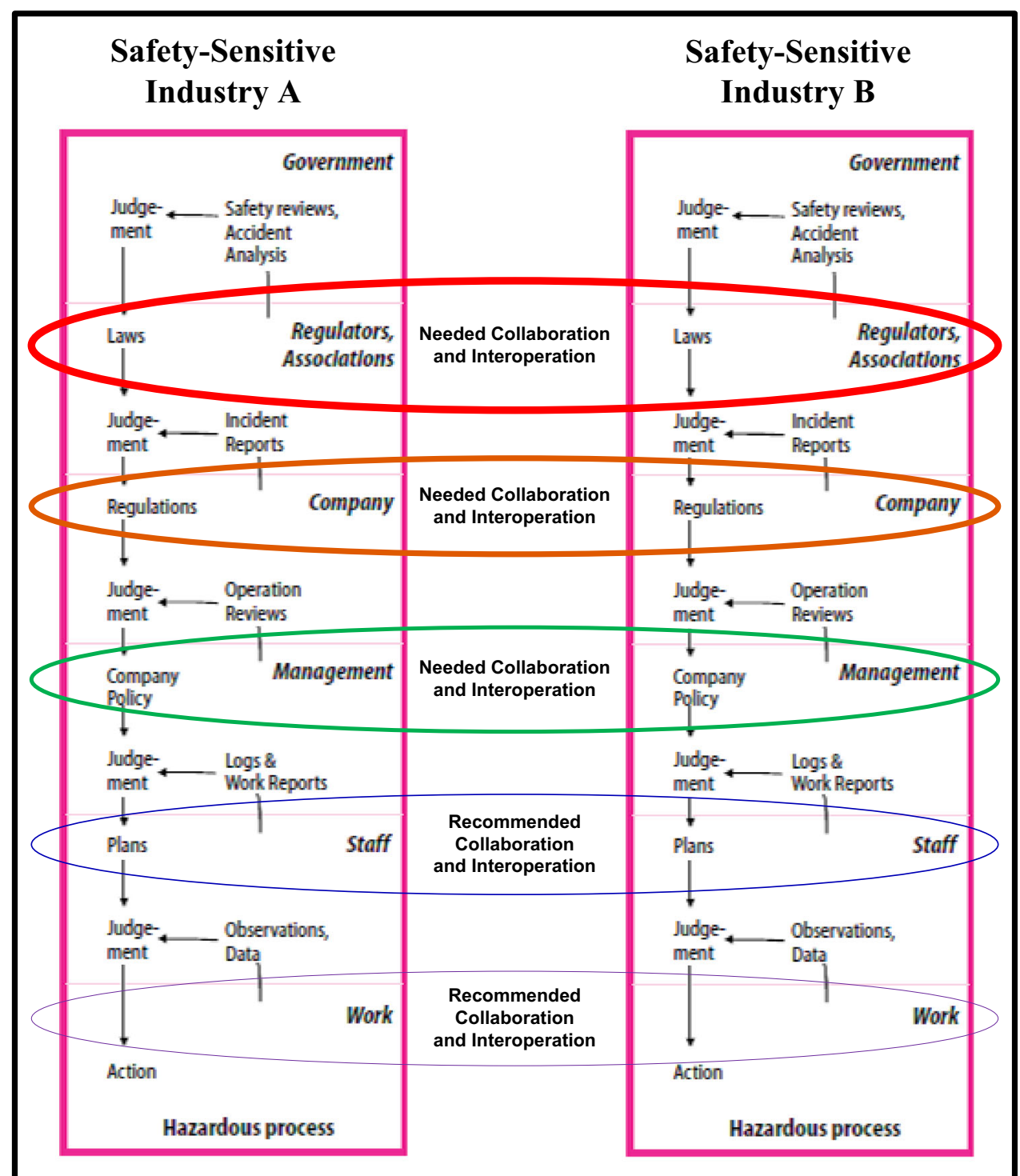

had reached the intakes of the desalination plant in Fujairah, UAE (Elshorbagy and Elhakeem 2008). In July 1997, diesel fuel spilled from a grounded barge in Sharjah, UAE, entered the intake of a desalination plant and led to a major contamination of the water supply of an estimated half million people (Elshorbagy and Elhakeem 2008).

\subsection{A Model for the Needed Inter-Country Coordination and Collaboration Among Responsible Actors and Entities}

Responsible entities for safety-sensitive industries in each of the Persian Gulf states not only need to closely interact with each other within their own country, but also collaborate with their counterparts in other countries to improve safety and prepare the most efficient and comprehensive emergency response framework. The proposed model in Fig. 9 needs to be expanded to include bilateral and multilateral collaboration and cooperation between multiple agencies from different countries (inter-country interactions) (Fig. 10).

A regional entity to coordinate and oversee the cooperation and interoperability between any two Persian Gulf countries across the key six layers of government, regulators, company, management, staff, and work should be devised and considered (Fig. 10). The role of the regional oversight entity should be expanded to ensure the effective and smooth interaction and interoperability between all eight Persian Gulf countries and their associated safetysensitive industries. This doubly integrated (at both the 
A regional oversight

coordinating

multi-lateral entity

Country X; e.g. Iran or UAE

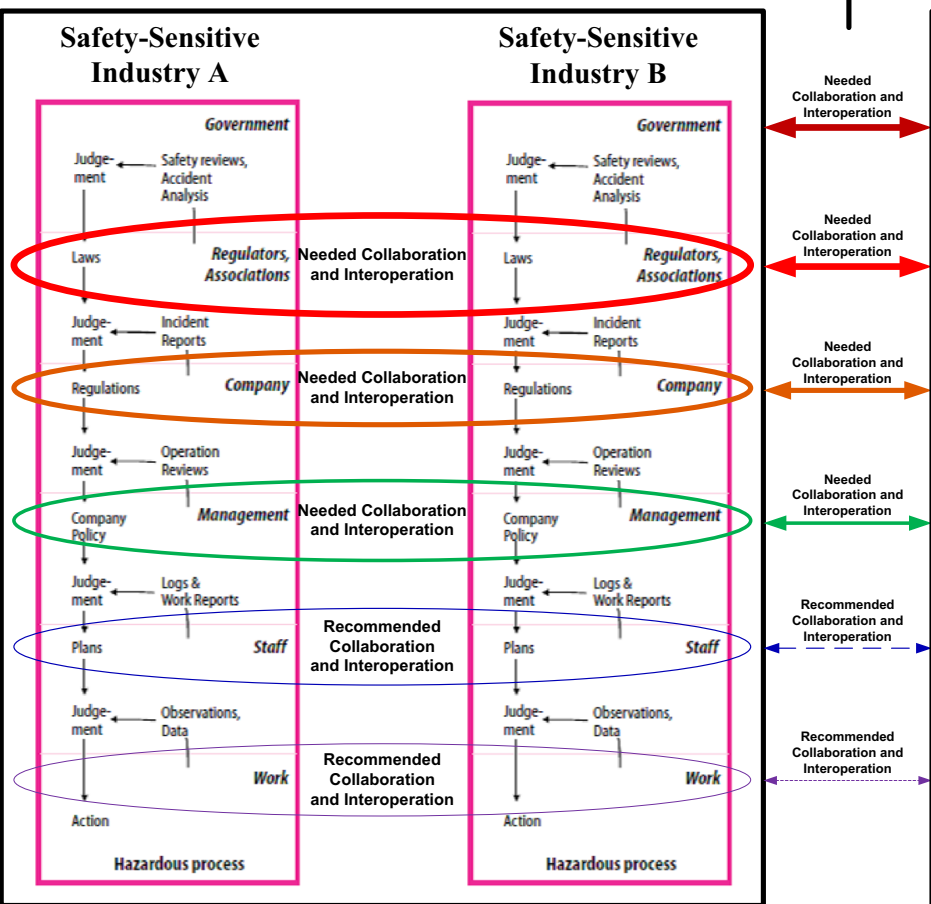

Country Y; e.g. Qatar or Saudi Arabia

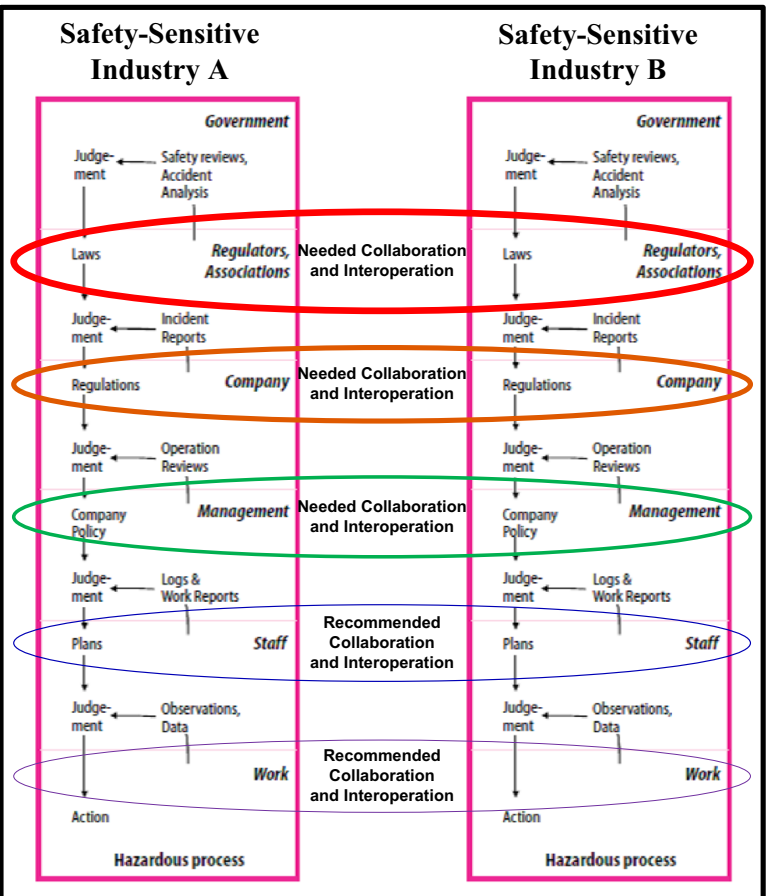

Fig. 10 Proposed model of the necessary interactions between key entities that affect the safety and emergency response of a sample of two major safety-sensitive industries (nuclear power, offshore oil and

intra- and inter-country levels) regional emergency response concept is presented in Fig. 11.

Such an oversight entity can be an entirely new organization or a new division within the Regional Organization for the Protection of the Marine Environment (ROPME), an already existing regional intergovernmental and multilateral organization in the Persian Gulf, to which all eight Persian Gulf states belong. The objective of this regional organization is to coordinate the Member States efforts for the protection of the water quality in the Persian Gulf (which is referred to as "ROPME Sea Area (RSA)") and to protect the environment (ROPME 2015). ROPME reports that it is playing an essential role in unifying the exerted efforts of the member states towards the protection of the marine environment and in following up the procedures of each member state.

\section{Some Specific Recommendations on How to Realize the Integrated Regional Emergency Response Concept in the Persian Gulf}

The regional community of the Persian Gulf should be seriously concerned about the lack of a system-oriented and integrated emergency response strategy in the Persian gas drilling, and seawater desalination) between two Persian Gulf countries, for example, Iran and the United Arab Emirates. Source Adapted from Rasmussen and Svedung (2000)

Gulf and the vulnerability of the whole ecosystem to a man-made or natural disaster. An accidental release of contaminants, which could have the combined effects of the Fukushima and the BP Deepwater Horizon disasters, with a disastrous impact on the Persian Gulf's already stretched, stressed, and fragile ecosystem, based on regional history and local realities, should not be dismissed as an improbable event.

\subsection{The State of Emergency Response in the Persian Gulf}

The ROPME, in its latest State of the Marine Environment report (ROPME 2013), concluded that governance and the management of the ecosystem "is fragmented at both the Regional and the National levels" (p. 28), and that "there is a dire need for closer cooperation among the ROPME Member States sharing the Sea Area" (emphasis added, p. 28). The organization argued that "the environment is not compartmentalized and nor should environmental policies be" (p. 27), and considered regional cooperation between and among the Persian Gulf countries as "vital for sustainable management of the RSA ecosystem" (p. 26). "The countries of the Region, therefore, are to adapt a 


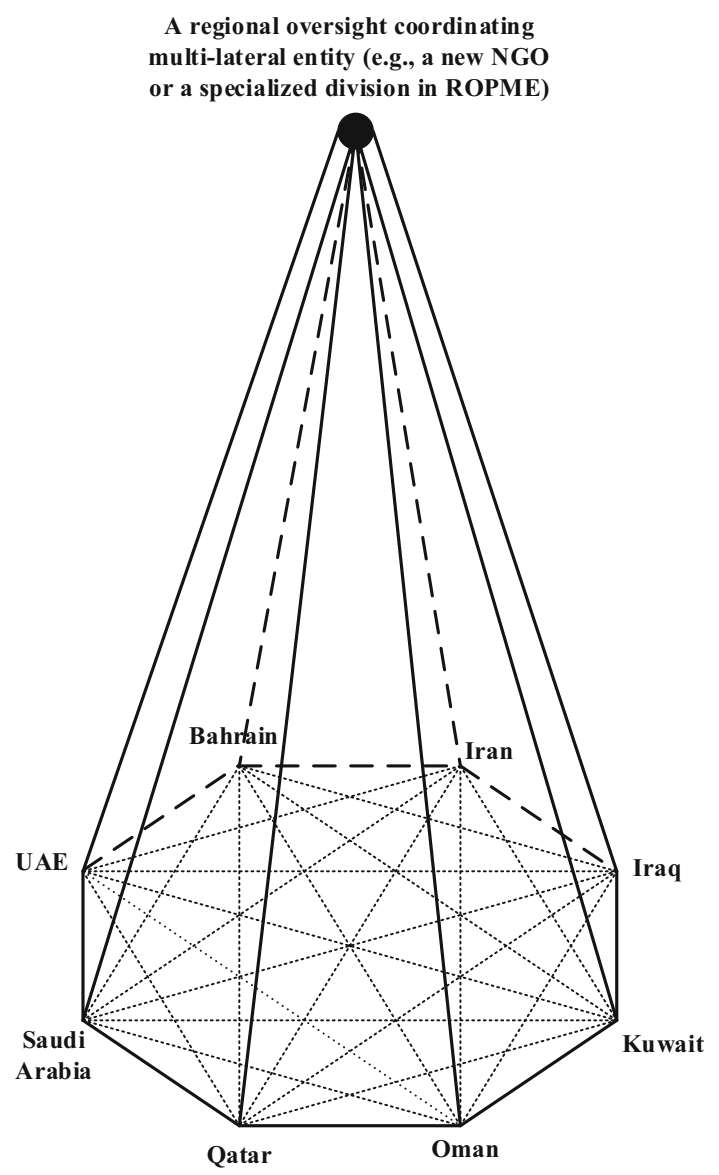

Fig. 11 An integrated regional emergency response concept to ensure full-scale cooperation and coordination and complete interoperability of emergency responders from all eight countries of the Persian Gulf. ROPME regional organization for the protection of the marine environment

long-term integrated strategic planning approach and a Road Map for the sustainable development of RSA, to achieve a healthier environment for a superior quality of life for all the people" (emphasis added, p. 29).

\subsection{Specific Features and Potential Contributions of the Proposed Integrated Model}

The set of interrelated proposed models of this study provides a solution suite in answer to the "dire need" for closer cooperation and a coordinated emergency response in the Persian Gulf. In order to launch and operationalize the proposed models in this study, either a new nongovernmental organization (NGO) can be established or the ROPME_-which has already developed limited provisions for radiological and nuclear emergency response plans-should be given additional responsibilities and resources to empanel and empower a standing major new division. The main function of this new entity would be to coordinate targeted research and development efforts as well as emergency responses to mishaps in safety-sensitive industries, such as nuclear power and seawater desalination plants as well as offshore oil and gas drilling and production platforms of member countries, with two separate but parallel subdivisions, one for plant operators and one for (hopefully, independent) regulators. This new ROPME entity could lay the foundation for a to-be-created multidisciplinary international and interregional center of excellence for coordination, cooperation, and collaboration on research and training on safety-sensitive, large-scale technological systems, including all major safety-sensitive industries in the region.

This effort can be modeled after the Joint Research Centre of the European Commission in Ispra, Italy. The US Government should also support Persian Gulf countries cooperation and the new ROPME initiative. The Gulf Nuclear Energy Infrastructure Institute (GNEII)—which is administered by the Sandia National Laboratories and conducts joint programs with the UAE_-should be expanded to include other technologies and to support this new initiative for cooperation on emergency responses in the Persian Gulf.

Creating a specialized new agile NGO or expanding the roles and responsibilities of the existing ROPME based on the observed needs should not be regarded as the creation of a new bureaucracy. The purpose of this new initiative is to expand the scope of ROPME's roles and responsibilities to oversee and coordinate the implementation of the proposed models of this study.

\subsection{Potential Contributions of the Proposed Integrated Model to Developing and Enhancing the Effectiveness of a Collective Incident Command System (ICS) in the Persian Gulf}

The systematic integration of the human element with the other components in an ICS is of critical importance to the effectiveness and eventual success of the ICS in response to any emergency. This issue was highlighted by Jensen and Waugh Jr (2014). It has been a cross-cutting major factor in the efficacy of the three conceptual categories that lead to reliable ICS performance-Structuring Mechanisms, Constrained Improvisation, and Cognition Management Methods_as identified by Bigley and Roberts (2001).

Human-systems integration is the cornerstone of the integrated proposed model of this study and is an attempt to address the requirement for a reliable and better informed ICS. It is believed to be a noteworthy contribution and an important addition to ROPME's already existing limited provisions in terms of interaction and coordination of all participating countries' emergency response systems 


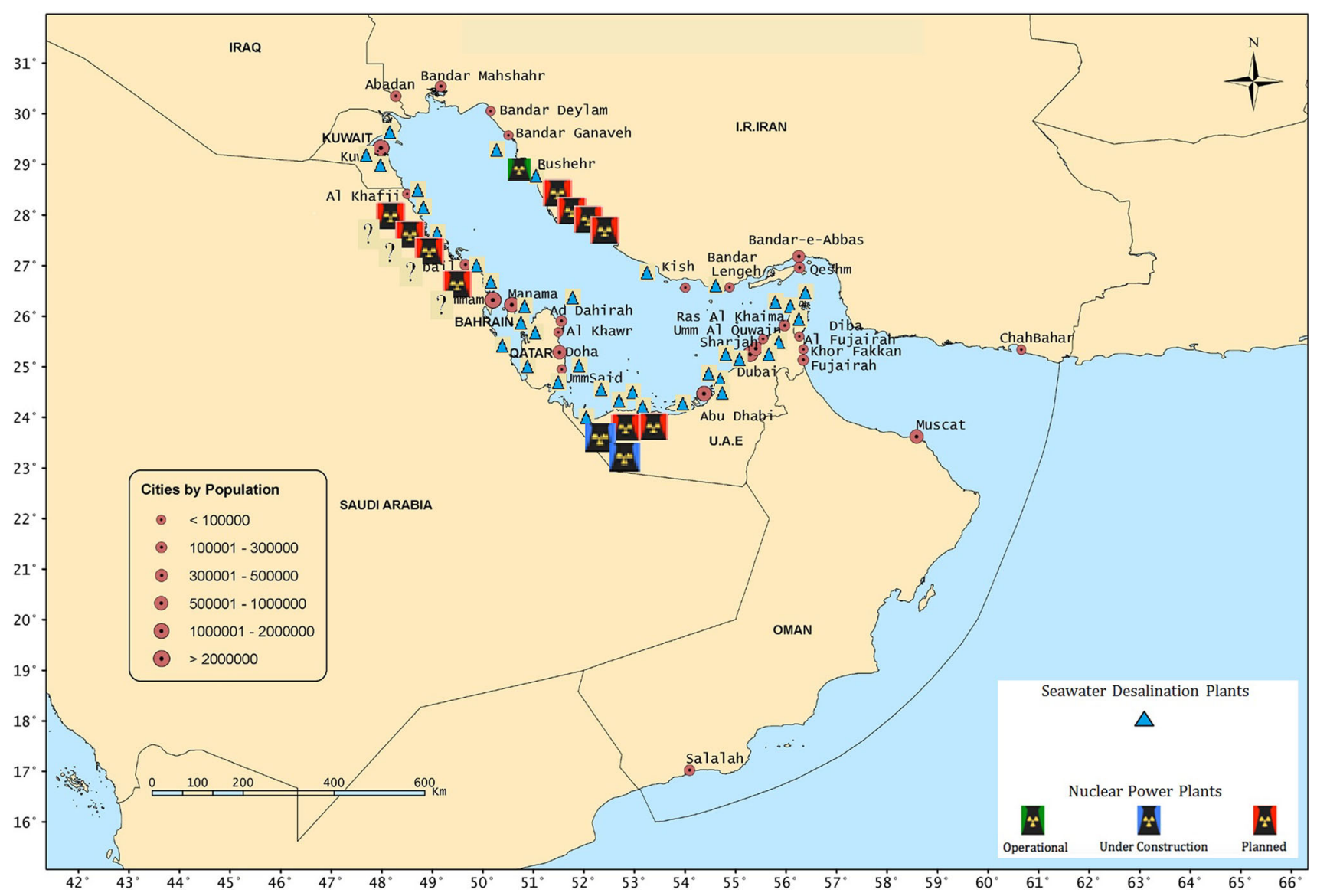

Fig. 12 Locations of major seawater desalination and nuclear power plants in the Persian Gulf and their proximity to dense coastal population areas (question marks indicate the unknown exact location and number of planned nuclear power plants by the Kingdom of Suadi

and their various human-organizational-technological subsystems.

\section{Model Generalizability: Application to the Black Sea}

The problems that affect the Persian Gulf are not unique to that region. These problems are being felt in other parts of the world with similar socio-technical dimensions. The need for a system-oriented approach towards emergency response collaborative activities is equally significant around the Black Sea, for example, another semiclosed sea that faces similar safety and sustainability challenges. The Black Sea and its straits have traditionally been the main route for transporting oil from the Caucasus area to Europe, though "today the traffic intensity of the Turkish straits has reached the limit, while liquid bulk terminal capacity is growing" (Osheyko 2013, p. 76). But there are an estimated 7 billion barrels of fossil fuel recoverable resources under the deep-water areas of the Black Sea (IEA 2011),
Arabia on the Persian Gulf coast). Source ROPME (2013, p. 6); seawater desalination plant data from World Bank (2012); nuclear power plant data from World Nuclear News (2015a, 2016a, b)

and Turkey is starting to explore these reservoirs. They are typically located in depths of more than $2000 \mathrm{~m}$, requiring ultra-deepwater drilling to a depth of over $5000 \mathrm{~m}$, which is "of the highest complexity [... that] usually involves high risks and several associated problems" (Wilson 2012, p. 92; Meshkati et al. 2012). The Black Sea will also be the site for Turkey's second and third planned nuclear power plants, in the coastal cities of Sinop (which could have up to four nuclear reactors) and Igneada, respectively (Hurriyet Daily News 2011; World Nuclear News 2015b).

\section{Conclusion: Engineering Diplomacy and Confidence Building in the Persian Gulf}

The scientific communities and governments of the eight Persian Gulf countries should embark on an urgent multilateral cooperation and systematically address the safety and sustainability of their energy and water resources within and among all the countries of the region. These countries should come to a collective understanding and 
recognition to address emergency response issues in a system-oriented (and not a piecemeal or bilateral) manner. The Persian Gulf states should be concerned with the vulnerability of their whole ecosystem to a man-made or natural disaster given the large number and proximity of seawater desalination plants and nuclear power plants to each other, as well as offshore oil and gas operations and maritime shipping (Fig. 12). These states should recognize the urgent need to balance their domestic sovereignty with regional responsibility, devise an agreement on how to proceed together, and develop a regional all-inclusive center for cooperation on safety, security, and sustainability, as well as emergency response.

Science and engineering are human intellectual endeavors that have always strived to rise above political and diplomatic affairs. In addition to safety and sustainability, one important by-product and unintended positive consequence of the proposed system-oriented and integrated emergency response models, which essentially and inherently are about engineering diplomacy and confidence building, could be better relations among the Persian Gulf countries (Meshkati 2012). Former US Secretary of State, Dean Acheson, emphasized that, "not all the arts of diplomacy are learned solely in its practice. There are other exercise yards" (Acheson 1969, p. 62).

The interdependencies of the Persian Gulf countries and their absolute reliance on the Gulf waters-which according to Iran's Foreign Minister Mohammad Javad Zarif (2013) are also their "shared lifeline [... and they] depend on it, not just for survival, but to thrive,"-heightens the vital need for system-oriented, integrative, and collaborative approaches towards the safety and sustainability of all complex technological systems. Effective interactions and interoperability of various subsystems, both in routine and non-routine (for example, emergency) situations should be addressed proactively. Zarif (2013) emphasized that, "with our fates so closely tied together, the belief that one's interests can be pursued without consideration of the interests of others is delusional."

As the recent events in the Gulf of Mexico and off the coast of Japan have demonstrated, without proactively considering human-organizational-technological factors in complex systems operations and response to their emergencies, sustainability could only be a short-lived dream and prosperity would be a disappearing mirage for millions of people in the Persian Gulf.

Acknowledgments We would like to thank many professors and scholars at the University of Southern California (USC), Viterbi School of Engineering, and School of International Relations, as well as from Persian Gulf country institutions for their inputs and comments. We are grateful to engineering graduate students, Mr. Ali Farshid and Ms. Ghena Alhanaee, for their assistance and research findings concerning desalination and nuclear power in the Persian
Gulf. This work, however, should not necessarily be construed as the above-mentioned individuals' representative position(s).

Open Access This article is distributed under the terms of the Creative Commons Attribution 4.0 International License (http://crea tivecommons.org/licenses/by/4.0/), which permits unrestricted use, distribution, and reproduction in any medium, provided you give appropriate credit to the original author(s) and the source, provide a link to the Creative Commons license, and indicate if changes were made.

\section{References}

Acheson, D. 1969. Present at the creation: My years at the State Department. New York: Norton \& Company.

Alderman, L. 2010. Dubai faces environmental problems after growth. The New York Times, 28 October 2010, p. B1.

Allianz Global Corporate \& Specialty. 2015. Global claims review 2015: Business interruption in focus (global trends and developments in business interruption claims). Munich: Allianz Global Corporate \& Specialty SE.

Bachellerie, I.J. 2012. Renewable energy in the GCC Countries: Resources, potential, and prospects. Gulf Research Center. http://library.fes.de/pdf-files/bueros/amman/09008.pdf. Accessed 30 Aug 2016.

Bigley, G.A., and K.H. Roberts. 2001. The incident command system: High-reliability organizing for complex and volatile task environments. Academy of Management Journal 44(6): 1281-1299.

Birkland, T.A., and S.E DeYoung. 2011. Emergency response, doctrinal confusion, and federalism in the Deepwater Horizon oil spill. The Journal of Federalism 41(3): 471-493.

Buesseler, K. 2014. Fukushima and ocean radioactivity. Oceanography 27(1): 92-105.

Clarke, L. 1999. Mission improbable: Using fantasy documents to tame disaster. Chicago: The University of Chicago Press.

Cicero, M.T. 1923. Divination. Book II, with an English translation by W.A. Falconer. London: Harvard University Press.

Department of Homeland Security. 2004. National incident management system. Washington, DC: Department of Homeland Security.

Eaton, C. 2015. Spill debt could hit BP for several years, ratings agency says. http://www.houstonchronicle.com/business/energy/ article/Spill-debt-could-hit-BP-for-several-years-6343084.php. Accessed 20 Jun 2015.

Elshorbagy, W., and A.-B. Elhakeem. 2008. Risk assessment maps of oil spill for major desalination plants in the United Arab Emirates. Desalination 228(1-3): 200-216.

FAO (Food and Agriculture Organization of the United Nations). 2009. Iran (Islamic republic of). http://www.fao.org/nr/water/ aquastat/countries_regions/irn/index.stm. Accessed 1 Jul 2015.

Garwin T., N. Pollard, and R. Tuohy (eds.). 2004. Project responder: National technology plan for emergency response to catastrophic terrorism. Prepared by Hicks and Associates, Inc. for The National Memorial Institute for the Prevention of Terrorism and the United States Department of Homeland Security.

Haapkylai, J., F. Ramade, and B. Salvat. 2007. Oil pollution on coral reefs: A review of the state of knowledge and management needs. Vie Milieu-Life \& Environment 57(1/2): 91-108.

Hurriyet Daily News. 2011. Town near Bulgaria may host Turkey's third nuclear plant, 6 April 2011. http://www.hurriyetdailynews. com/default.aspx ?pageid $=438 \& n=$ town-near-bulgaria-bordermay-host-turkeys-third-nuclear-plant-2011-04-06. Accessed 20 Jun 2015. 
IAEA (International Atomic Energy Agency). 1988. Nuclear safety report for 1987. Vienna, Austria: IAEA.

IEA (International Energy Agency). 2011. World energy outlook. Paris: OECD (Organisation for Economic Co-operation and Development)/IEA

Jensen, J., and W.L.Waugh Jr. 2014. The United States' experience with the incident command system: What we think we know and what we need to know more about. Journal of Contingencies and Crisis Management 22(1): 5-17.

Kalantari, I. 2015. Forced migration is the fate of millions of Iranians (An interview in Persian). http://shahrvand-newspaper.ir/ Default.aspx?NPN_Id=224. Accessed 1 Jul 2015.

Lattemann, S., and T. Höpner. 2008. Environmental impact and impact assessment of seawater desalination. Desalination 220(1-3): 1-15.

Lochbaum, D., E. Lyman, and S.Q. Stranahan. 2014. Fukushima: The story of a nuclear disaster. New York: Union of Concerned Scientists, The New Press.

Madany, I.M., A. Jaffar, and E.S. AI-Shirbini. 1998. Variations in the concentrations of aromatic petroleum hydrocarbons in Bahraini coastal waters during the period October 1993 to December 1995. Environment International 24(1-2): 61-66.

McKinsey \& Company. 2002. Increasing FDNY's preparedness. http://www.nyc.gov/html/fdny/html/mck_report/toc.html. Accessed 1 Jul 2015

Meshkati, N. 1990. Preventing accidents at oil and chemical plants. Professional Safety 35(11): 15-18.

Meshkati, N. 1991. Human factors in large-scale technological systems' accidents: Three Mile Island, Bhopal, Chernobyl. Organization \& Environment 5(2): 133-154.

Meshkati, N. 1992. Ergonomics of large-scale technological systems. Impact of Science on Society 165: 87-97.

Meshkati, N. 1995. Human factors in process plants and facility design. In Cost-effective risk assessment for process design, ed. R. Deshotles, and R. Zimmerman, 113-130. New York: McGraw-Hill.

Meshkati, N. 2010. A framework for a joint emergency response and crisis management center: Personal experience, challenges and potential for building confidence and creating collaboration. Paper presented at the Middle East Regional Security and Cooperation Conference, Athens, Greece, 31 July 2010.

Meshkati, N. 2012. Engineering diplomacy: An underutilized tool in foreign policy. Science and Diplomacy 1(2): 20-30.

Meshkati, N. 2014. Atoms for peace in the Persian Gulf: The vital byproduct of P5+1 nuclear agreement with Iran. http://www. huffingtonpost.com/najmedin-meshkati/atoms-for-peace-inthe-pe_b_4552716.html. Accessed 1 Jul 2015.

Meshkati, N., G. Calis, and A. Celebi. 2012. Perils of Turkey's newfound black gold in the black sea. Hurriyet Daily News, 11 June 2012. http://www.hurriyetdailynews.com/perils-of-turkeysnewfound-black-gold-in-the-black-sea-.aspx?pageID $=449 \& \mathrm{n}$ ID $=22816 \&$ NewsCatID=396. Accessed 20 Jun 2015.

Meshkati, N., and Y. Khashe. 2015. Operators' improvisation in complex technological systems: Successfully tackling ambiguity, enhancing resiliency and the last resort to averting disaster. Journal of Contingencies and Crisis Management 23(2): 90-96.

Meshkati, N., M. Tabibzadeh, A. Farshid, M. Rahimi, and G. Alhanaee. 2016. People-technology-ecosystem integration: A framework to ensure regional interoperability for safety, sustainability and resilience of interdependent energy, water and seafood sources in the (Persian) Gulf. Human Factors: The Journal of Human Factors and Ergonomics Society 58(1): 43-57.

Mivehchi, M. 2015. Iran plans to supply drinking water via desalination for 9 million people (An interview in Persian). http://www.dolat.ir/NSite/FullStory/News/?Serv=0\&Id=208902. Accessed 1 Jul 2015
NAE/NRC (National Academy of Engineering and National Research Council). 2011. Macondo well Deepwater Horizon blowout: Lessons for improving offshore drilling safety. Washington, DC: The National Academies Press.

NAS/NRC (National Academy of Sciences and National Research Council). 2014. Lessons learned from the Fukushima nuclear accident for improving safety of U.S. nuclear plants. Washington, DC: The National Academies Press.

National Commission on the BP Deepwater Horizon Oil Spill and Offshore Drilling. 2011. Deepwater: The Gulf oil disaster and the future of offshore drilling. Washington, DC: US Government Printing Office.

NRDC (Natural Resources Defense Council). 2015. Summary of information concerning the ecological and economic impacts of the BP Deepwater Horizon oil spill disaster. http://www.nrdc. org/energy/gulfspill/files/gulfspill-impacts-summary-IP.pdf. Accessed 30 Aug 2016.

Osheyko, S. 2013. Russia-EU upcoming energy projects: Sustainable development issues. In Energy Security in the Wider Black Sea Area - National and Allied Approaches, ed. E. Lyutskanov, L. Alieva, and M. Seragimova, 74-82. Amsterdam, Netherlands: IOS Press.

Rasmussen, J. 1997. Risk management in a dynamic society: A modeling problem. Safety Science 27(2): 183-213.

Rasmussen, J., and I. Svedung. 2000. Proactive risk management in a dynamic society, 1st edn. Karlstad, Sweden: Risk and Environmental Department, Swedish Rescue Services Agency (Raddningsverket).

Reynolds, R.M. 1993. Physical oceanography of the Gulf, Strait of Hormuz, and the Gulf of Oman-Results from the Mt. Mitchell expedition. Marine Pollution Bulletin 27(1): 35-59.

Rollenhagen, C. 1997. The relationship between humans, technology and organization - An introduction (Sambandet människa, teknik och organization - en introduction). Lund, Sweden: Utbildningshuset Studentlitterature.

ROPME (Regional Organization for the Protection of the Marine Environment). 2013. State of the marine environment report (SOMER). http://www.ropme.org/Uploads/Events/EBM/03SOMER_2013.pdf. Accessed 28 Jun 2015.

ROPME (Regional Organization for the Protection of the Marine Environment). 2015. ROPME objectives. http://ropme.org/ ROPME\%20Objectives.clx. Accessed 28 Jun 2015.

Russia Beyond the Headlines. 2013. Russia interested in cooperation on civilian nuclear energy use with Iran - Lavrov, 11 December 2013. http://rbth.com/news/2013/12/11/russia_interested_in_ cooperation_on_civilian_nuclear_energy_use_with_ira_32491. html. Accessed 3 Jul 2015.

Saif, O. 2012. The future outlook of desalination in the gulf: Challenges \& opportunities faced by Qatar \& the UAE. Master's thesis, McMaster University, Hamilton, Ontario, Canada.

Sale, P.F., D.A. Feary, J.A. Burt, A.G. Bauman, G.H. Cavalcante, K.G. Drouillard, B. Kjerfve, E. Marquis, C.G. Trick, P. Usseglio, and H. Van Lavieren. 2011. The growing need for sustainable ecological management of Marine Communities of the Persian Gulf. AMBIO 40(1): 4-17.

Skjerve, A.B., and M. Kaarstad. 2014. The MTO perspective research activities at the Halden Project. In Proceedings of the Technical Meeting on the Interaction between Individuals, Technology and Organization - A Systemic Approach to Safety in Practice, 10-13 June 2014, International Atomic Energy Agency (IAEA) Headquarters, Vienna, Austria. https://gnssn.iaea.org/NSNI/SC/ TM_ITO/Papers/Skjerve_Kaarstad_The\%20MTO\%20Safety\% 20Perspective $\% 20$ and $\% 20$ Selected $\% 20$ Research $\% 20$ Activ ities\%20Halden\%20Project_Paper.pdf. Accessed 28 Jun 2015. 
Swift, S., and A. Bower. 2003. Formation and circulation of dense water in the Persian/Arabian Gulf. Journal of Geophysical Research 108(C1): 4-1-4-21.

Tabibzadeh, M. 2014. A risk analysis methodology to address human and organizational factors in offshore drilling safety: With an emphasis on negative pressure test. Doctoral dissertation. University of Southern California, Los Angeles, CA.

Tabibzadeh, M., and N. Meshkati. 2014a. A risk analysis study to systematically address the critical role of human and organizational factors in negative pressure test for the offshore drilling industry: Policy recommendations for HSE specialists. In Proceedings of the SPE International Conference on Health, Safety and Environment, SPE 168559. 17-19 March 2014, Long Beach, California, USA. http://dx.doi.org/10.2118/168559-MS.

Tabibzadeh, M., and N. Meshkati. 2014b. Learning from the BP Deepwater Horizon accident: Risk analysis of human and organizational factors in negative pressure test. Environment Systems and Decisions 34(2): 194-207.

Tabibzadeh, M., and N. Meshkati. 2015. Safety culture in oil and gas operations: A risk analysis framework to address communication and interoperation of multiple interacting organizations. In Proceedings of the SPE E\&P Health, Safety, Security and Environmental Conference-Americas, SPE 173508-MS. 16-18 March 2015, Society of Petroleum Engineers, Denver, Colorado. http://dx.doi.org/10.2118/173508-MS

Trieb, F., and H. Mullersteinhagen. 2008. Concentrating solar power for seawater desalination in the Middle East and North Africa. Desalination 220(1-3): 165-183.

Tierney, K. 2006. The red pill. Understanding Katrina: Perspectives from the social sciences. New York: Social Sciences Research Council. http://understandingkatrina.ssrc.org/Tierney/. Accessed 22 Jul 2015.

USCG (United States Coast Guard). 2011. BP deepwater horizon oil spill: Incident specific preparedness review. https://www.uscg. mil/foia/docs/DWH/BPDWH.pdf. Accessed 1 Jul 2015.
Wang, Z., S.F. DiMarco, A.E. Jochens, and S. Ingle. 2013. High salinity events in the northern Arabian Sea and Sea of Oman. Deep-Sea Research I 74: 14-24.

Wilson, A. 2012. Overcoming black sea ultradeepwater drilling challenges. Journal of Petroleum Technology 64(5): 88-92.

World Bank. (2012). Renewable energy desalination: An emerging solution to close the water gap in the Middle East and North Africa. http://water.worldbank.org/sites/water.worldbank.org/ files/publication/water-wpp-Sun-Powered-Desal-Gateway-Meet ing-MENAs-Water-Needs_2.pdf. Accessed 25 Jun 2015.

World Nuclear Association. (2015a). Nuclear power in Saudi Arabia. http://www.world-nuclear.org/info/Country-Profiles/CountriesO-S/Saudi-Arabia/. Accessed 3 Jul 2015.

World Nuclear Association. (2015b). Emerging nuclear energy Countries. http://www.world-nuclear.org/info/Country-Profiles/Others/ Emerging-Nuclear-Energy-Countries/. Accessed 3 Jul 2015.

World Nuclear News. (2015a). Reactor vessel installed at Barakah 2, 18 Jun 2015. http://www.world-nuclear-news.org/NN-Reactorvessel-installed-at-Barakah-2-1806154.html. Accessed 1 Jul 2015.

World Nuclear News. (2015b). Ground broken for Turkey's first nuclear plant, 15 April 2015. http://www.world-nuclear-news. org/NN-Ground-broken-for-Turkeys-first-nuclear-power-plant1541501.html. Accessed 23 Jun 2015.

World Nuclear News. (2016a). Steam generators installed at third Barakah unit, 17 August 2016. http://www.world-nuclear-news. org/NN-Steam-generators-installed-at-third-Barakah-unit1708164.html. Accessed 23 Aug 2016.

World Nuclear News. 2016b. Iran ready to share nuclear experience, 15 September 2016. http://world-nuclear-news.org/NP-Iranready-to-share-nuclear-experience-1609167.html. Accessed 16 Sept 2016.

Zarif, M.J. (2013). Our neighbors are our priority. Asharq Al-Awsat, 21 November 2013. http://www.aawsat.net/author/m-zarif. Accessed 23 Jun 2015. 